\title{
Література
}

1. В Центральном Комитете КПРСС и Совете Министров СССР // Биология в школе. - 1978. - № 2. C. 6-11. 2. Екзаменаційні білети з біології на атестат за середню освіту (IX - X класів масових шкіл та X - XI класів вечірніх (змінних) і заочних шкіл) на 1971/72 навчальний рік // Збірник наказів та інструкцій Міністерства освіти Української РСР. - 1971. - № 18. - С. 5-8. 3. Коптєва Е. М. Вивчення біології за новими програмами / Е. М. Коптева // Радянська школа. - 1970. - № 6 - С. 43-48. 4. Освоение новых программ, совершенствование преподавания биологии - неотложная задача учителя // Биология в школе. - 1969. - № 4. - С. 3-5. 5. Очерки истории школы и педагогической мысли народов СССР (1961 -1986 гг.): [отв. ред. Паначин Ф. Г. и др.]. - М. : Педагогика, 1987. - 416 с. 6. Політехнічне навчання в курсі біології в середній школі: [відпр. ред. Ф. Л. Лесик]. - К. : Радянська школа, 1957. - 135 с. 7. Положення про навчальний кабінет біології середньої загальноосвітньої школи: Затверджено колегією Міністерства освіти УРСР 6 серпня 1975 року // Збірник наказів та інструкцій Міністерства освіти Української РСР. - 1975. - № 20. - С. 14-23. 8. Положення про республіканський конкурс на кращу дослідницьку роботу з біології та сільського господарства у восьмирічних і середніх школах та позашкільних закладах Української РСР // Збірник наказів та інструкцій Міністерства освіти Української РСР. - 1971. - № 9-10. - С. 24-27. 9. Положення про республіканський конкурс на кращу дослідницьку роботу з біології та сільського господарства в загальноосвітніх школах і позашкільних закладах Української РСР: Загальні положення // Збірник наказів та інструкцій Міністерства освіти Української РСР. - 1984. - №7. - С. 16-21. 10. Положення про факультативні заняття в загальноосвітній школі Української РСР: Затверджено Міністр. освіти УРСР О. М. Маринич 17 березня 1975 р. // Збірник наказів та інструкцій Міністерства освіти Української РСР. - 1975. - № 9. - С. 15-17. 11. Примірна програма для самоосвіти вчителів біології // Збірник наказів та інструкцій Міністерства освіти Української РСР. - 1968. - № 23. - С. 3-22. 12. Про введення курсу загальної біології в 1966/67 навчальному році в Х класах: наказ № 68 від 12 березня 1966 р. // Збірник наказів та інструкцій Міністерства освіти Української РСР. - 1966. - № 7. - С. 17-20. 13. Про заходи дальшого поліпшення роботи середньої загальноосвітньої школи // Збірник наказів та інструкцій Міністерства освіти Української РСР. - 1966. - № 23. - С. 2-12. 14. Про посилення охорони природи і поліпшення використання природних ресурсів // Збірник наказів та інструкцій Міністерства освіти Української РСР. - 1973. - № 6. - С. 25-26. 15. Про проведення в 1971/72 навчальному році олімпіад юних математиків, фізиків, хіміків, біологів, географів-краєзнавців, істориків, літераторів та знавців іноземних мов: наказ № 339/802 від 23 листопада 1971 р. // Збірник наказів та інструкцій Міністерства освіти Української РСР. - 1972. - № 1. - С. 6-10. 16. Про стан викладання за удосконаленими програмами, якість знань, умінь і практичних навичок учнів 3 біології у загальноосвітніх школах республіки: Рішення колегії Міністерства освіти УРСР від 25.01.1984 р. // Збірник наказів та інструкцій Міністерства освіти Української РСР. - 1984. - № 6. - С. 3-20. 17. Румянцева М. Н. Повышать эффективность и качество биологического образования / М. Н. Румянцева, А. Н. Мягкова, Б. Д. Комиссаров // Биология в школе. - 1976. - № 5. - С. 3-8.

\section{ЕКОЛОГІЗАЦІЯ ШКІЛЬНОГО КУРСУ ГЕОГРАФІЇ В 90-ТІ РОКИ}

Оржаховська А. Г. Екологізації шкільного курсу географії в 90-ті роки.

У статті висвітлено зміст поняття «екологізація географії», розглянуто роль педагогічної преси в еколого-виховному процесі, подано приклади впровадження екологічних знань у різних навчальних закладах і залучення школярів до розв'язання проблем навколишнього середовища.

Ключові слова: екологічна освіта та виховання, екологічна відповідальність, екологізація географії, педагогічна преса.

Оржаховская А. Г. Экологизация школьного курса географии в 90-е годы.

В статье раскрывается понятие «экологизация географии», рассматривается роль педагогической прессы в эколого-воспитательном процессе, приведены примеры внедрения экологических знаний в различных учебных заведениях и привлечение школьников к решению проблем окружающей среды.

Ключевые слова: экологическое образование и воспитание, экологическая ответственность, экологизация географии, педагогическая пресса. 
Orzhahovska A. G. School geography course ecologization in the 90s.

The article deals with the concept «ecologization of geography», examines the role of pedagogical media in environmental education process, gives examples of environmental knowledge implementation into different educational institutions and students' involving into environmental problems solving.

Key words: ecological education, ecological responsibility, ecologization of geography, pedagogical media.

Час, коли людство почало зазнавати негативних результатів антропогенного впливу на довкілля, екологічні проблеми стали одними з найглобальніших. Екологічні ситуації, які загрожують усьому живому в різних регіонах земної кулі, почали фіксувати науковці і громадські діячі.

Вагомий унесок у вивчення проблем екологічного навчання та виховання зробили українські науковці та педагоги. Філософський аспект екологічного виховання розглядався у працях М. Кисельова, В. Крисаченка, Г. Пустовіта та ін. Теоретико-методологічні основи екологічного виховання у школі відображаються в працях В. Червонецького, С. Шмалєй та ін.

Метою статті є аналіз проблем висвітлення екологічного виховання у 90-ті роки минулого століття на сторінках основних педагогічних видань.

Нами проаналізовано наукові публікації в журналі «Географія в школі» за 90 -ті роки XX ст. Це видання мало значний наклад і попит як серед науковців, так і серед освітян-практиків.

Сучасна наука екологія розв'язує безліч питань, використовує різноманітні методи, принципами, які не можна назвати суто біологічними.

Більшість науковців продовжують відносити ії до біологічних наук, але побутують думки, що екологія - це нова ланка, яка поєднує всі природничі, точні, гуманітарні й соціальні науки. Цього погляду дотримуються М. Реймерс, Г. Голубєв, О. Яблоков, О. Яншин, Г. Ягодін, О. Лаптев, Д. Медоуз, Т. Міллер, К. Монтгомері та багато інших відомих вітчизняних та зарубіжних дослідників. Екологію почали відносити як до біологічної, так і до географічної галузі знань, іiі розглядали як цілком самостійну науку.

Важливе значення у формуванні екологічної свідомості має вивчення природничих наук. Вони формують уявлення про природні екосистеми та ресурси, забруднення довкілля. Підготовка майбутніх педагогів природничо-географічних спеціальностей потребує розвитку активної дослідницької діяльності студентів. У комплексі природоохоронної діяльності важливою є участь студентів у проведенні лекцій, бесід, які підвищують екологічну освіченість населення. Активна участь студентів на всіх етапах роботи розвиває в них почуття важливості свого завдання. Здобувши навички конкретної роботи з охорони навколишнього середовища, студенти - майбутні педагоги природничо-географічних дисциплін - можуть реалізувати свої знання в подальшій діяльності [4].

Географія вивчає взаємодію природи, населення, господарства в конкретних умовах. Можна дійти висновку, що саме цей науковий підхід дозволить уникнути помилок у природокористуванні. Накопичення знань повинно починатись зі стін школи, їх повинні забезпечувати програми та підручники, уважали Ю. Дмитревський та В. Сухоруков. Саме 3 підручником вони пов'язували перспективи розвитку ефективного навчального процесу [2].

Іншої думки був I. Журавльов, уважаючи, що удосконалення підручника не дасть бажаного результату, на який можна було б розраховувати за відповідних умов його використання. Автор пише, що потрібно змінити ставлення вчителів до можливостей чинних підручників [3].

Щоб покращити методичну підготовку майбутніх викладачів природничих наук, автори Л. Панчешникова та I. Душина пропонують такі принципи:

- Фундаментальність методичної підготовки в поєднанні $з$ практичною спрямованістю.

- Міжпредметні зв'язки 3 психолого-педагогічними дисциплінами, дисциплінами географічного циклу та суспільними науками;

- Формування методичних умінь - поєднання знань, практичних умінь та елементів творчої діяльності.

- Наголошення на основних аспектах методичної підготовки (проблемне навчання, дослідницький метод навчання, колективні форми організації навчальної діяльності, лекційносемінарська система навчання - все, що зумовлює відмінність сучасного уроку від традиційного). 
- Орієнтація курсу методики навчання географії на краєзнавчу роботу в школі, підготовку майбутніх учителів до організації самостійної дослідницької роботи учнів на місцевості.

- Реалізація в навчальній діяльності студентів психолого-педагогічних вимог до процесу навчання.

- Підготовка майбутніх учителів з урахуванням перспектив розвитку школи і географічної науки.

Автори наголошували, що для реалізації цих принципів необхідно вже на перших заняттях запевнити студентів у необхідності і важливості методики в роботі вчителя [10].

В. Преображенський у своїй статті пише, що такі проблеми, як збереження чистоти повітря, чистоти води, особливо в містах, не можуть бути розв'язаними на грунті біологічних знань. Автор наголошує, що не слід розглядати екологічні проблеми з суто біологічної чи географічної точки зору, а як проблему двох наук, яка потребує спільного розв'язання. Аналізуючи програми (1986р.) для 5-9 класів, він дійшов висновку, що тематика кожного класу має передбачати розгляд екологічної проблематики. Вже у процесі створення підручників відповідно до програми намагались впровадити екологічний матеріал в інші розділи [11].

Прагнула показати місце і роль екологічного виховання в освітньому процесі Н. Винокурова, його значення і шляхи взаємозв'язку шкільних предметів біологія і географія в екологічній освіті школярів. Науковець уважала, що розв'язання екологічних проблем корелює із поглядом на природу як на універсальне явище, а не як джерело ресурсів. Виходячи 3 цього, зміст екологічної освіти передбачає поряд зі знаннями і ціннісні орієнтації щодо природи [1].

На допомогу вчителям група авторів пропонує концепцію базового змісту природничих дисциплін, основними принципами якої є:

- Безперервність природничо-наукової освіти в основній школі.

- Викладання в школі курсів фізики, хімії, біології, географії та астрономії.

- Уведення інтегрованого курсу природознавства як основного предмета в 1-6 класах.

- Уведення блочної структури природознавства 3 розподілом на окремі дисципліни, починаючи з 7 класу.

- Побудова змісту природничо-наукової освіти за принципом сходинок: від найменшого до найбільшого.

- Урахування психологічних особливостей школярів щодо засвоєння окремих природничих дисциплін [8].

Є. Ривкін наголошував, що екологізація шкільного курсу географії надає змогу вчителю висвітлити причинно-наслідкові зв'язки в системі «природа - людина - промисловість», ознайомити 3 соціальною екологією та геоекологією; зробити навчання більш цікавим, використовувати проблемний метод навчання, показати можливість використання екологічних знань на практиці. Автор стверджував, щоб досягти більшого результату, потрібно ідеї шкільної екологізації географічної освіти застосовувати на уроках різних типів та в позакласній роботі [12].

На сторінках журналу Т. Комісарова та А. Мурашова пропонують приклади викладу екологічних знань у різних навчальних закладах: у школах - впроваджували різні уроки географії, у коледжах, ліцеях - експедиції, походи, табори різного профілю. Досвід такої роботи дозволив створити педагогічну систему, яка грунтується на принципі єдності пізнання з діяльністю під час формування уявлень про ландшафти, геосистеми та їх екологічний стан [5; 9].

Взаємодія природи і суспільства, раціональне природокористування можливі лише за умови оволодіння екологічними знаннями. Упровадженням цих знань в освітній процес зацікавились науковці Т. Кучер, В. Латинов, Н. Латинова та Н. Родзевич. Ними розроблено авторські програми, спрямовані на формування екологічної культури підростаючого покоління. Особливостями програм був узагальнювальний характер змісту, який розкривався на конкретних проблемах природокористування. Такий підхід дозволяє не тільки систематизувати отримані учнями знання з різних предметів (історія, біологія, географія), а й підводить випускників школи до усвідомленого розуміння своєї ролі збереження життя на Землі.

Програма В. Латинова й Н. Латинової містила матеріали з екології, фізичної та економічної географії, країнознавства, етнографії, а також з астрономії, фізики, хімії, геології, біології, медицини, історії тощо. Матеріал викладався в найбільш цікавій формі, робота проводилась в діалозі з дітьми, коли проблеми розв'язуються спільно [7]. 
Н. Родзевич пропонує програму профільного курсу, під час якого планує використовувати картографічні матеріали атласів і підручників. Він зазначає, що екологічний потенціал можна розкрити за допомогою системи питань та завдань, спрмямованих на аналіз природних $\mathrm{i}$ господарсько-економічних карт [13].

Програму курсу «Економіка та екологія» Т. Кучера було запропоновано в двох варіантах: для середніх загальноосвітніх шкіл задля екологізації змісту географічного курсу та для шкіл екологічного профілю. У ній розглядались питання екологічної діяльності, яка дозволила б найбільш ефективно використовувати природні умови і ресурси за найменших втратах для довкілля [6].

Авторські програми передбачали систематизацію екологічного матеріалу 3 подальшим друкуванням посібників, у яких пропонувались різні форми та методи: лекції, семінари, спільні обговорення ключових проблем. Особливу увагу було приділено вмінню працювати з різними джерелами інформації.

Зміст програм передбачав практичні та самостійні роботи. Значну частину складали групові завдання, передбачалось проведення занять 3 різновіковими групами школярів на місцевості для закріплення знань і набуття практичних навичок $[6 ; 7 ; 13]$.

Проаналізувавши статті аналізованого журналу, ми дійшли висновку, що зростає розуміння ролі екологічних проблем у житті суспільства. Йшлося про екологічні проблеми людства, від результату розв'язання яких залежить доля кожного із нас і доля спільноти. У зв’язку з цим змінюється зміст поняття «екологізація» географії в школі. Екологізація стає провідною метою у формуванні нової концепції освіти, якої можна досягти шляхом корегування програм і підручників за рахунок уведення елементів екологічної освіти. Водночас результати дії аналізованих програм під час урочної та позаурочної роботи залишаються недостатньою мірою дослідженими і потребують подальшого вивчення.

\section{Література}

1. Винокурова Н. Ф. Взаимосвязь географических и биологических знаний в экологическом образовании школьников / Н. Ф. Винокурова // География в школе. - 1991. - № 3. - С. 39-44. 2. Дмитревский Ю. Д. Экономическая география СССР в школе / Ю. Д. Дмитревский, В. Д. Сухоруков // География в школе. - 1991. - № 1. - С. 27-30. 3. Журавлев И. К. Учебник на уроке / И. К. Журавлев // География в школе. - 1991. - № 1. - С. 24-27. 4. Камалов Л. Ф. Методические аспекты природоохранного образования / Л. Ф. Камалов // География в школе. - 1991. - №1. - С. 41. 5. Комисарова Т. С. Обучающая природа, или неформальное геоэкологическое образование / Т. С. Комисарова // География в школе. - 1995. - № 3. - С. 55-56. 6. Кучер Т. В. Программа курса «Экономика и экология» / Т. В. Кучер // География в школе. - 1993. - № 3. - С.41-44. 7. Латынов В. Л. «Географическая экология человека»- новый курс для школы / В. Л. Латынов, Н. Е. Латынова // География в школе. - 1992. - № 4-5. - С. 18-23. 8. Моженова А. Б. Концепция базового содержания естествознания основной школы Казахстана / А. Б. Моженова, К. Н. Мамирова, К. А. Сарманова, Д. М. Казахбаева, Ж. Д. Молдабеков // География в школе. - 1993. - № 2. - С. 34-36. 9. Мурашова А. И. Экологизация географических знаний / А.И. Мурашова // География в школе. - 1995. №3. - С. 53-55. 10. Панчешникова Л. М. О новом подходе к методической подготовке студентов в педвузе / Л. М. Панчешникова, И. В. Душина // География в школе. - 1991. - № 2. - С. 30-35. 11. Преображенский В. С. Что нам нужно? Экологические элементы в программе или ведущая роль экологического подхода? / В. С. Преображенський // География в школе. - 1991. - № 3. - С. 37-39. 12. Ривкин Е. Ю. Экологизация школьного географического образования / Е. Ю. Ривкин // География в школе. - 1993. - №3. - С. 29-32. 13. Родзевич Н. Н. Программа профильного курса «Глобальные и региональные экологические проблемы» / Н. Н. Родзевич // География в школе. - 1993. - № 4. - С. 35-37.

\section{ОРГАНІЗАЦІЯ АТЕСТАЦІЇ ПРОФЕСІЙНОЇ ДІЯЛЬНОСТІ ПЕДАГОГІВ У ГРЕЦІЇ}

Проценко О. Б. Організація атестації професійної діяльності педагогів у Греції.

У статті визначено нормативно-законодавчу базу, зміст та умови організації атестації педагогічних кадрів у Греції. Виявлено критерії, за якими здійснюється оцінювання професійної діяльності вчителів. Охарактеризовано основні види атестації (атестація шкільним консультантом та директором школи) і етапи їх реалізації.

Ключові слова: педагог, атестація, післядипломна освіта. 